\title{
Kisgyermeknevelők nyelvi stratégiái a gyermeki kommunikáció támogatásában
}

\author{
KLEIN ÁgNes - TANCZ TüNDE \\ Pécsi Tudományegyetem
}

\begin{abstract}
Az anyanyelv elsajátitásával kapcsolatos kérdéseket régóta vizsgálják a különbözö tudományterületek (pl. filozófia, pszichológia, pedagógia, nyelvészet) képviselői. Az utóbbi években számos tanulmány foglalkozott a gyermekek nyelvi fejlödésével, a fejlödés szakaszaival és jellemzöivel, az eltérö nyelvi fejlödés korai felismerésével és terápiájával. A nyelvi fejlödés átfogó analizise és a fejlesztési lehetöségek számbavétele mindezek mellett megkivánja a nyelvi input jelentöségének hangsúlyozását. A humánökológiai megközelités (Bronfenbrenner, 1979) a környezet jelentöségét hangsúlyozza a gyermek fejlódésében, és együtt kezeli az individuális életkörülményeket, valamint a társadalmi-kulturális hatásokat. Az „input-hipotézis” (Krashen, 1985) szerint a nyelvelsajátítás csak megfelelö mennyiségü és minöségü nyelvi hatás segitségével lehetséges, azaz a gyermeknek megfelelö nyelvi mintát és támogatást kell biztosítani a kora gyermekkorban. A nyelvi input kapcsán jelentösége van az életkornak. A nyelvelsajátításra az agy a szenzitív periódusban a legfogékonyabb, ezen az időszakon túl a fejlödés lassabb, és az eredmény sem tökéletes. A kora gyermekkor kezdetén a nyelvi input tagadhatatlanul az édesanyáktól és a közvetlen családi környezetböl érkezik, az intézményesitett neveléssel kiszélesednek a nyelvi források és hatások. A jelen vizsgálat azt mutatja be, hogy milyen nyelvelsajátitást befolyásoló stratégiákat (módszereket) alkalmaznak a kisgyermeknevelók a bölcsődei interakciókban, továbbá arra fókuszál, hogy ezek mennyire képesek biztositani és támogatni a gyermek nyelvi fejlödését az adott életkorban.
\end{abstract}

Kulcsszavak: nyelvelsajátítás, bölcsődei beszédfejlesztés, dajkanyelv, pedagógiai kommunikáció, társas interakció

\section{A bölcsőde mint a nyelvi szocializáció színtere}

A kisgyermek szociális terének első és leggyakoribb intézményesített bővülési formája és fejlődését befolyásoló közege a bölcsőde. A bölcsődék szolgáltató intézmények, melyek a szülők munkavégzésének idejére, vagy egyéb ok miatt végzik szakma-specifikus elvárásoknak megfelelően a rájuk bízott gyermekek szakszerű gondozását, nevelését és felügyeletét. A bölcsődei nevelés-gondozás célja: „A családban nevelkedő kisgyermek számára a családi nevelést segítve, napközbeni ellátás keretében a gyermek fizikai és érzelmi biztonságának és jóllétének megteremtésével, feltétel nélküli szeretettel és elfogadással, a gyermek nemzetiségi/etnikai hovatartozásának tiszteletben tartásával, identitásának erösitésével kompetenciájának figyelembevételével, tapasztalatszerzési lehetőség biztositásával, viselke- dési minták nyújtásával elösegíteni a harmonikus fejlödést" (Balogh és mtsi., 2012. 16. o.).

2017. január 1-jétől a gyermekvédelmi törvény módosításának eredményeként alapvetően átalakult a gyermekek napközbeni ellátásának rendszere. A három évesnél fiatalabb gyermekek napközbeni ellátására a korábbiaknál rugalmasabb ellátási formákat alakítottak ki. Az új formák a települések kisgyermekkorú népességszámához, valamint a munkahelyi adottságokhoz igazodva biztosítják a legkisebbek bölcsődei elhelyezését. A gyermekek napközbeni ellátását bölcsőde, mini bölcsőde, családi bölcsőde, munkahelyi bölcsőde és napközbeni gyermekfelügyelet formájában lehet nyújtani. A bölcsőde és a mini bölcsőde intézményes formában kínál ellátást, a családi és a munkahelyi bölcsőde szolgáltatásként vehető igénybe. A mini bölcsődékben kisebb létszámú, 7-8 fös csoportokban biztosítanak gondozást a gyermekeknek, a családi és a 
Kisgyermeknevelők nyelvi stratégiái a gyermeki kommunikáció támogatásában

munkahelyi bölcsődék alacsonyabb csoportlétszámmal, 5-7 fővel működhetnek. Minden ellátási formában lehetőség van az egészségesen fejlődő gyermekek mellett a sajátos nevelési igényü gyermekek ellátására is. Az utóbbi évtizedben, hazánkban dinamikusan növekedett a bölcsődei nevelésben részt vevő gyermekek száma. 2018-ban a 4 bölcsődei ellátási formában a beíratott gyermekek létszáma elérte a 44577 főt. A bölcsődei ellátás alapvetően a 0-3 évesek gondozására szakosodott intézmény, ugyanakkor az intézménybe beíratott gyermekek mintegy 30\%-a már betöltötte a 3. életévét ( $K S H, 2019)$.

A Bölcsődei nevelés-gondozás országos alapprogramja (15/1998. (IV. 30.) NM rendelet a személyes gondoskodást nyújtó gyermekjóléti, gyermekvédelmi intézmények, valamint személyek szakmai feladatiról és müködésük feltételeiröl 10. sz. melléklete ${ }^{1}$ ) kiemelt feladataként jelöli meg a gyermekek beszédkészségének fejlesztését, ennek érdekében az ingerekben gazdag, tiszta nyelvi környezet biztosítását, a kommunikációs kedv felkeltését és fenntartását a bölcsődei nevelés-gondozás minden helyzetében, mondókák, énekek, versek, mesék közvetítésével. A gyermekkel való napi együttlét során számtalan interakciós helyzet adódik. A nevelők ezeket használják fel a gyermek megerősítése és fejlesztése érdekében. Az interakciók megjelenhetnek a kötött és kötetlen tevékenységekbe beépülve, de ezektől függetlenül is. „Az interakciós helyzetek nagy figyelmet érdemelnek, mert a gyermek fejlödését, belső gyarapodását döntö módon az interakciók napi mennyisége, mélysége (érzelmekkel, sokirányú információs lehetöséggel való telítettsége) határozza meg" (Bimbó, 2015. 223. o.).

A kommunikációs helyzetekben tekintetbe kell venni és méltányolni kell azoknak a gyermekeknek a nyelvi szükségleteit is, akiknek nem a magyar az anyanyelvük. A korai időszak eseményei különös jelentőséget kapnak a tipikustól eltérő fejlődésű gyermek esetében, ezért kiemelt figyelmet kell fordítani a

\footnotetext{
${ }^{1}$ Egy 2020. március 9-én kelt jogszabálymódosítás (6/2020. (III. 6.) EMMI rendelet 8. \$,) kivette a rendelet mellékletéből az alapprogramot.
}

sajátos nevelési igényű és a hátrányos helyzetű gyermekek társas és érzelmi kompetenciáinak fejlesztésére, szükség esetén más segítő szakemberek bevonásával. Mindazokkal a szakemberekkel együtt kell működni, akikkel a családok kapcsolatba kerülnek, illetve akikkel a kooperáció a gyermek egészséges fejlödése és fejlesztése szempontjából szükséges.

\section{A nyelvi fejlődés területei és mérföldkövei}

A korszerű pszicholingvisztikai felfogás szerint az anyanyelv a gyermekkorban elsajátított kommunikációs eszköz, amellyel a gondolatok nyelvi formába önthetők és másokkal közölhetők, valamint amelynek révén mások közlésének észlelése és megértése történik. "Úgy is fogalmazhatunk, hogy az anyanyelvelsajátítás az a folyamat, amelynek során birtokba vesszük az emberi nyelv egy specifikus változatát, a gyermek elsajátítja a produkciós és a percepciós jellemzőket, valamint a használati stratégiákat" (Gósy, 2017. 9. o.).

A társadalmi boldogulás, az esélyegyenlőség szempontjából a nyelvi fejlődés és a beszédképesség alapvető fontosságú. A nyugati típusú társadalmakban meghatározó a gyermekek fejlődésében és a felnőttek életminőségében. Befolyásolja a további nyelvek elsajátítását, a kognitív készségek fejlődését, a kommunikatív kompetenciák müködését, és az emberi kapcsolatok alakításának képességét (Gecső, 2006). Az alap kultúrtechnikák (olvasás, írás, számolás) elsajátítása is szorosan összefügg az anyanyelv elsajátításával, és prognosztizálja az iskolai beválást. A nyelvi szocializáció során a gyermek egy adott közösségnek nyelvileg és kulturálisan kompetens tagjává válik.

$\mathrm{Az}$ anyanyelv elsajátítása elkerülhetetlen, egységes és sikeres folyamat (Meisel, 2003). A nyelvelsajátító képesség és a szociális környezet összjátékának köszönhetően minden fiziológiailag és mentálisan egészséges gyermek viszonylag gyorsan és egységesen megtanul beszélni. A nyelvtanulás a méhen belüli életben a magzati nyelv kialakulásával veszi kezdetét és kb. 14 éves korban éri el a felnőttkorra jellemző nyelvi fejlettségi szintet. Az 
anyanyelv fejlődése univerzálisan érvényes fázisokra bontható, melyek meghatározott sorrendben követik egymást, például az egyszavas közlések korszaka egy éves kor körül, a szókincs robbanásszerű bővülése és a kétszavas mondatok megjelenése a második év során, a nyelvtani morfémák és az összetettebb szintaktikai struktúrák megjelenése a harmadik évben, lényegében a teljes grammatikai rendszer elsajátítása az ötödik életév végére (Gósy, 2005). Az elsajátítás tempója valamint a nyelvi elemek elsajátításának sorrendje ugyanakkor egyéni és csoportos eltéréseket mutat. Ezeket a különbségeket részben öröklött, részben környezeti tényezők határozzák meg. A nyelvtanért felelős neurális rendszer például nagyon érzékeny a nyelvi tapasztalatban mutatkozó késésre (Weber-Fox \& Neville, 1996), és a szocioökonómiai státusz nyelvi szocializációs mintái, valamint a feldolgozási kapacitás egyéni különbségei is jelentősen befolyásolják a nyelvi fejlődést (Bates és mtsai., 1995). Az elsajátítás tehát a legkülönfélébb organikus, funkcionális, pszichés vagy környezeti okok miatt válhat atipikussá. Az elmaradások egyrészt az egyén képességdeficitjei, másrészt a környezeti támogatás eltérései, illetve ezek kölcsönhatásai lehetnek (Fehér, Kas és Pintye, 2018). Mivel minden gyermek egyénileg kerül kapcsolatba a nyelvvel, ezért sok egyéni változata létezik. Nincs két egyforma gyermeknyelv, bár ezeknek a változatoknak sok közös vonása van (Tancz, 2011).

A gyermek az anyanyelv elsajátítása során olyan képességek birtokába jut, melyek segítségével alkalmassá válik gondolatainak megformálására és átadására. Megismerkedik a nyelvi szintekkel (a fonetikával, a szemantikával, a szintaxissal és a pragmatikával), a nyelv egymásra épülö, egymásból kibontakozó részeivel (a hangokkal, a szavakkal, a mondatokkal) és az adott szituációnak megfelelő használati elvekkel. Megtapasztalja a kommunikáció három, egymással szervesen öszszefüggő komponensét: a szegmentális vagy tagolt (pl. beszédhang, szótag, szó, mondat stb.), a szupraszegmentális vagy folytonos (pl. hangszín, hanglejtés, intonáció, időtartam stb.) és az extralingvális vagy nyelven kívüli (pl. mimika, gesztus. testtartás, távolság, nem nyelvi hangadás stb.) jeleket. A nyelvi jelek többsége szimbolikus, ezért a szimbólumok és szabályok megfejtésére és képzésére vonatkozó készségeket és képességeket is meg kell tanulnia. A nyelvelsajátítás folyamatában tehát a gyermek 1. elsajátítja anyanyelvének hangzókészletét, 2. szótárat épít, 3. megtanulja a nyelvtani szabályokat és a szabályok alóli kivételeket, 4. megtanulja a nyelvet különféle kommunikációs szándékok kifejezésére használni (Gósy, 2017).

Ahhoz, hogy a gyermek a környezetével kapcsolatos tapasztalatait integrálni tudja, szüksége van a fejlettségével és viselkedésével harmonizáló feltételekre. A nyelvi képesség a személyközi kapcsolatokon, a kommunikáción keresztül fejlődik, ezért a gyermekek nyelvelsajátításában kiemelt szerepe van az előzetes tapasztalatoknak, eseményeknek, érzelmeknek és a beszédfeldolgozásban szerzett gyakorlatnak.

\subsection{A dajkanyelv szerepe a nyelvelsajátításban}

A gyermek nyelvi fejlettségét meghatározza, hogy környezetétől milyen beszédmintát és mennyi nyelvi ingert kap. A beszédminták egyik sajátos kerete a szülők, gondozók gyermekekhez intézett speciális beszéde az ún. dajkanyelv. A dajkanyelv az a beszédmód vagy beszédstílus (regiszter), ami a csecsemőt az adott kultúra nyelvének és nyelvhasználatának világába bevezeti. A világ minden kultúrájában jelen van valamilyen formában, tehát kulturálisan átszármaztatott és konvencionalizált, de nem univerzális jelenség, hiszen minden nyelvnek megvan a saját dajkanyelve. „A dajkanyelvnek nevezett terminus technikus magyar nyelvü speciális jelentéstartalma nyelvtudományi értelemben a gyermek nyelvelsajátítási folyamatának óvatos körülölelését(!) azaz dajkálását is jelentheti" (Koós, 2017. 97. o.). Jellegzetességei az egyszerü mondatok, az egyszerű szavak, az egyszerű, tiszta és egyértelmű hangsúlyozás, a magas hangfekvés, a kérdő jellegü intonáció a mondatvégeken, a lassabb beszéd, és a hosszabb szünetek használata (Lengyel, 
Kisgyermeknevelők nyelvi stratégiái a gyermeki kommunikáció támogatásában

1981; Réger, 2002; Kátainé, 2008). Mondanivalója helyhez és időhöz kötődik, a szituációra korlátozódik, a gyermek számára fontos tárgyakra, személyekre és cselekvésekre utal, „sok ismétlést tartalmaz, egyszerü morfológiát és szintaxist, valamint a kommunikációs helyzethez kötött szókincset használ" (Gósy 2005. 298. o.). Különösen fontos a dajkanyelv melódiája, ami a kicsiknek szavak nélkül is információt közvetít. A kísérletek azt is alátámasztották, hogy a dajkanyelvre jobban odafigyelnek a csecsemők, mint a felnőttekhez szóló beszédre, továbbá hosszabban emlékeznek azokra, akik dajkanyelven kommunikáltak velük (Fernald, 1985).

A szülők és nevelők ösztönösen alkalmazzák a dajkanyelvi kommunikáció nyelvi és nyelven kívüli elemeit, például mimikával és gesztikulációval is igazodnak a gyermek jelzéseihez. Ez az egyszerűsített, és ritmikusan ismétlődő nyelvi input megjelöli a fontosabb nyelvi elemeket, elősegíti a beszédhangok elsajátítását, a beszédfolyam szavakká szegmentálását, és szabályozza az interakciót (Klann-Delius, 1999). Ösztönzi és ébren tartja a gyermekek nyelvre, kommunikációra vonatkozó figyelmét, igényt ébreszt a hasonló kapcsolat kezdeményezésére, és megadja a minimális inputot a további szintre való lépéshez (Kátainé, 2008).

\subsection{Az utánzás szerepe a nyelvtanulásban}

A nyelvi produkciós rendszer a korai évektől kezdve a felnőtt minta alapján szerveződik. A gyermek leszúkítve utánoz: utánzásai nem pontosak, leegyszerűsítve imitálják a felnőtt beszédét (Butzkamm \& Butzkamm, 2008). A gyermek azért imitál, hogy az éppen megtanultat gyakorolja. Az utánzás egyaránt vonatkozik a szókincsre, a mondattanra és a társalgási eljárásokra (Réger, 1986). „Az utánzás tehát a saját rendszer kibövitésének eszköze, amelyen keresztül a gyermek szavakat tanul, illetve társas szerepeket ad vissza és gyakorol" (Pléh, 2006. 775. o.). A gyermek addig gyakorol, amíg az adott nyelvi elem túlsúlyba kerül a spontán beszédében, ezt követően az utánzás száma lecsökken. Húsz hónapos korban a gyermeki utánzás mértéke még jelentős, kétéves korra a harmadára csökken és a gyermeki megnyilatkozások csupán 20\%-a, három éves korra 2\%-ra szűkül (Pléh, Palotás és Lörik, 2002).

A tanulmányok jelentős része a gyermeki nyelvelsajátítás folyamatában, a nyelvi minta átadásában az anya-gyermek diádikus kapcsolatát emeli ki. A nyelvet átadó környezet azonban ennél szélesebb, hiszen a gyermekek diádikus és poliádikus kontextusokban más gyermekektől és felnőttektől is tanulnak. Barton és Tomasello (1994) például a testvérek szerepét hangsúlyozza. Megállapításuk szerint az idősebb testvér ösztönzi és elősegíti a prototársalgások kialakulását.

Számos kutatás támasztja alá a nyelvelsajátítás során a nyelvi input minőségének és mennyiségének fontosságát (Ritterfeld, 2000; Murray et al., 2006), melyet összekapcsolnak a környezet szerepével, az adott család szerkezetével és szocioökonómiai státusával.

\section{A pedagógiai kommunikáció jellemzői}

A pedagógiai kommunikáció a szociális kommunikáció egy különleges fajtája. Különlegessége jellegzetes funkciójában és szerepében mutatkozik meg. Legföbb sajátossága a kommunikatív kapcsolat fejlesztő, személyiséggazdagító szándéka. A pedagógiai kommunikáció a pedagógiai céloknak alávetett és pedagógiailag szabályozott, intézményi keretek között folyó, többé-kevésbé tervszerüen előkészített és levezetett kommunikáció, mely többnyire nevelők és növendékek közvetlen személyes kapcsolataiban, a nevelők által irányított illetve befolyásolt formában megy végbe, és szabályozott, strukturált nyelvezetre épül (Szőke-Milinte, 2013).

A bölcsődében zajló pedagógiai kommunikáció a nevelés-gondozás helyzeteihez és a napirendhez kötött, de hat rá a bölcsőde külső és belső környezete is, például az intézmény éthosza, tradíciói, szokásai és kommunikációs működése. A pedagógus kommunikációját be- 
folyásolják személyes adottságai, jellemvonásai, és előzetes tapasztalatai is, például saját kommunikációs mintázata, nyelvezete, enkódolási rendszere: a gondolatok szószimbólumokká, testmozgásokká, arckifejezésekké, gesztusokká alakítása. A kisgyermeknevelők kommunikációjának mennyiségi és minőségi mutatóit Zrinszky (2002) alapján foglaljuk össze:

A mennyiségi mutatók: 1. pedagógus közléseinek mennyisége, 2. gyermeki beszéd mennyisége, 3. kommunikatív tevékenységek ideje, tartama, 4. a médiumok és eszközök használatával töltött idő, 5. az előző pontok kommunikációs tevékenységeinek részaránya egy adott időn belül.

A minőségi mutatók: 1. a kommunikáció relevanciája és adekvátsága (a gyermek életkorához, szükségleteihez és igényeihez illeszkedés), 2. a kommunikáció központi témája, 3. a kommunikáció stílusa (a kifejeződő attitűdök, pl. gyermekszeretet, tolerancia, lelkesedés, elkötelezettség, közömbösség, ellenszenv, kiégettség stb.), 4. a gyermeki kommunikáció szabadsága 5. a kommunikáció irányítástechnikája (pl. a félénkebbek szerephez juttatása, a nagyhangúak kezelése stb.).

A pedagógus kommunikációját elsősorban az elfogadás, a pozitív érzelmi viszonyulás, a hitelesség és az ezeket összerendező koherens magatartás alapozza meg. Eredményességét jelentősen befolyásolja, hogy a pedagógus mennyire pontosan érzékeli és értelmezi a gyermek verbális és nonverbális jelzéseit. A gyermeki kommunikáció megértése nem könnyü. Az értelmezést bonyolítja, hogy sok élettani sajátosság jellemzi, és tükröződik benne a családi környezet sajátos hatása, valamint érvényesülnek benne a kibontakozó személyiség sajátos motivációi is. A nevelőnek empátiás készséggel kell rendelkeznie, és tudatosítani kell a nem-verbális kommunikáció hatásait, ez a kisgyermekek vonatkozásában különösen fontos (Buda, 2012).

Az otthoni környezetben a szülők és a családtagok keretet alkotó stratégiákat adva vezetik be gyermeküket az anyanyelv grammatikai és kommunikációs szabályaiba. A bölcsődébe lépve ezt a feladatot pedagógusok viszik tovább. A nyelvi megnyilvánulásokra nekik kell immár adekvát módon reagálniuk, és nekik kell ezeket kiterjeszteniük. Az új környezetben az otthoni környezethez hasonlóan fontos a megbízható, stabil kötődés kialakítása: az elfogadás, a gyermek személyiségének akceptálása, a nyitottság és érdeklődés a gyermek nyelvi megnyilvánulásai iránt. Grimm (1999) hangsúlyozza, hogy a nyelvi fejlödésre azok az interakciókban megjelenő megnyilatkozások hatnak ösztönzően, melyek a gyermek számára relevanciával rendelkeznek, melyek felkeltik és fenntartják figyelmét és érdeklődését.

A nyelv önmagában nem fejleszti a nyelvelsajátítást, amennyiben az nincs összehangolva a megértéséhez szükséges képekkel, cselekvéssel és a gyermek nem érzi, hogy az üzenet neki szól. A nyelv tanulását a felnőttek a következő stratégiákkal tudják hatékonyan segíteni: témához kapcsolódó kérdések, lehetséges feleletek, összetett kiegészítő válaszok, hibákat impliciten korrigáló reakciók (Farrar, 1992; Saxton, 2000). A nyelvi fejlesztések sokszínűsége szignifikánsan korrelál a gyermekek szókincsnövekedésével (Klein, 2013). A sokszínűség alatt a bölcsődében megjelenő témák és kommunikációs technikák változatosságát értjük. A sokoldalú és adaptív eljáráskészlet alkalmazkodik a gyermekek közötti egyéni különbségekhez. Lehetőséget teremt a gyermekközpontú életszervezésre, a differenciált bánásmódra, a nyelvi erőforrások és kompetenciák fejlesztésére.

\section{Kutatás}

\subsection{Kutatás felépitése}

Kutatásunk a bölcsődei interakciók minőségi aspektusaira fókuszált. A kisgyermeknevelők nyelvi fejlődést támogató kommunikációs stratégiáit vizsgáltuk, szakirodalmi szempontokra támaszkodva, saját kidolgozású interakciós kérdőív segítségével.

A kérdőívben szereplö kérdések kidolgozásában Dannenbauer (1999) interakcióelemzési szempontrendszerére építettük. A tanulmány a következő gyermeki megnyilvánulásokat megelőző (1. táblázat) és követő (2. táblázat) interakciókat jelölte meg. 
Kisgyermeknevelők nyelvi stratégiái a gyermeki kommunikáció támogatásában

\begin{tabular}{|c|c|c|}
\hline Megnevezés & Funkció & Példa \\
\hline Prezentáció & Célforma gyakori alkalmazása & Látod az autót? A piros autót? A pirosat! \\
\hline Párhuzamos beszéd & Gyermeki intenció verbalizálása & $\begin{array}{l}\text { Egy nagy autót szeretnél? Aha, biztos a } \\
\text { pirosat! Azt? }\end{array}$ \\
\hline Nyelvészeti markerek & Megfigyelt szituációs jellemző verbalizálása & $\begin{array}{l}\text { Igen, ez egy lapát a kezedben. A lapátok nem } \\
\text { a homokozóban maradnak. Hozd a lapátokat. }\end{array}$ \\
\hline Alternatív kérdések & Nyelvi struktúrák felkínálása & Látod a babát? Látsz egy babát valahol? \\
\hline
\end{tabular}

1. táblázat: Gyermeki megnyilvánulásokat megelőző interakciók

\begin{tabular}{|l|l|l|}
\hline \multicolumn{1}{|c|}{ Megnevezés } & \multicolumn{1}{|c|}{ Funkció } & \multicolumn{1}{c|}{ Példa } \\
\hline expanzió & $\begin{array}{l}\text { Gyermek megnyilvánulásának kiegészítése, } \\
\text { új struktúra beépítése }\end{array}$ & $\begin{array}{l}\text { Vava el. } \\
\text { Igen, elszaladt a kutyus. Bement a házába. }\end{array}$ \\
\hline átformálás & $\begin{array}{l}\text { Gyermek megnyilvánulásának átformálása, } \\
\text { új struktúra beépítése }\end{array}$ & $\begin{array}{l}\text { Vegyük ki a játékot! } \\
\text { Kivesszük a játékot? }\end{array}$ \\
\hline korrekció & Gyermek megnyilvánulásának javítása & Áni ett. Megetted? Ügyes vagy. \\
\hline utánzó önkorrekció & $\begin{array}{l}\text { Gyermek megnyilvánulásának utánzása és } \\
\text { javítása }\end{array}$ & Áni ett. Nem, nem ett, megette. \\
\hline extenzió & Gyermek megnyilvánulásának folytatása & Áni ett. Megetted a borsót? \\
\hline
\end{tabular}

2. táblázat: Gyermeki megnyilvánulásokat követő interakciók

Majd ezeket bővítettük ki Ritterfeld (2000. 419. o.) szempontrendszerével, mely szintén az interakciókban használt kommunikációs stratégiákat vizsgálta:

1. a gyermek beszédre ösztönzése (provokálása) tudatosan hamis információ megadásával,

2. vertikális dialógusstruktúrák felépítése a beszédaktusokban jelentkező koherencia alapján,

3. hosszabb ideig tartó közös gondolkodás a verbális interakciókban pl. szerepjátékok, problémák közös megoldása, közös tevékenységek egyeztetése,

4. dajkanyelv használata,

5. más gyerekek bevonása, a gyerekgyerek interakció előkészítése.

Az adatfelvétel a bölcsődékben dolgozó kisgyermeknevelők bevonásával készült, és Baranya, Fejér, illetve Tolna megyére koncentrálódott. Ez országos relációkban ugyan nem, de regionális mértekben lehetőséget ad a helyzet értékelésére és átgondolására. A kérdőívek elektronikus formában, snowball módszerrel kerültek a kitöltőkhöz. A kérdőív 20 könnyen áttekinthető, feleletválasztós, illetve néhány nyitott szöveges kérdést tartal- mazott. A kérdőívet 44 fö töltötte ki érvényes formában. A szerzők ezúton is köszönik a kollégáknak az adatszolgáltatást és az együttműködést.

Várakozásunk szerint eredményeink hozzájárulnak a kisgyermeknevelők kommunikációs kompetenciáit megerősítő programok, szakmai-módszertani javaslatok, képzések kidolgozásához és feltehetően további kutatásokat is indukálnak.

Az alábbiakban a kérdőíves kutatás néhány eredményét mutatjuk be.

\subsection{Demográfiai adatok bemutatása és elemzése}

A demográfiai adatokat a 3. táblázat szemlélteti. A kérdőívet kitöltő kisgyermeknevelők 47,7\%-a rendelkezik FOKSZ/FSZ/OKJ képesítéssel és 34\%-uk főiskolai diplomával, továbbá egy nevelő egyetemi végzettséget szerzett. A fennmaradó 17\%-nak nincs felsőfokú vagy ahhoz köthető végzettsége. A megkérdezettek majdnem 68\%-a kevesebb, mint 10 esztendőt dolgozott a szakmájában. 48\%-a pályakezdő, tehát szakmai tapasztalatuk 5 év alatti. 
Az életkorra nem kérdeztünk rá, ugyanakkor feltételezzük, hogy a válaszadók között azért jelentek meg nagyobb arányban a pályakezdők, mert az internetes kérdőívek kitöltése a fiatalabb korosztály számára volt technikailag egyszerűbb, könnyebben megvalósítható. A megkérdezettek három megye (Baranya, Fejér, Tolna) bölcsődéiben dolgoznak, e megyékből egyenlő arányban küldték vissza a kérdőíveket. A válaszadók több mint a fele 5-10 ezer fö közötti népességszámú kisvárosban, és mintegy harmada falvakban dolgozik. A három megye településstruktúrájára valóban a kisebb településtípusok jellemzők. A régió településszerkezete kedvezőtlen, arra egyrészt a városhálózat fejletlensége, másrészt az aprófalvak és kistelepülések aránya jellemző. A régió városai között főként a kisvárosok dominálnak.

A kérdőívekre adott válaszok egyértelmüen mutatják a települések (önkormányzatok), mint fenntartók dominanciáját. A bölcsődék helyzete a fenntartókat tekintve speciális, hiszen nemzetiségi önkormányzatok, egyházak, illetve a civil szektor és a nonprofit gazdasági szervezetek alig jelennek meg ebben a szegmensben. A magán bölcsődék száma elenyésző. A válaszokban a foglalkoztatók (cégek, vállalatok) által fenntartott munkahelyi bölcsődék egyáltalán nem szerepeltek. Ez az országos tendenciákkal szinkronban van, hiszen a 2017-2018-as nevelési évben az országban mindössze 8 munkahelyi bölcsőde működött, ezekből 5 a Közép-Dunántúlon, a 20 ezer főt meghaladó városokban (KSH, 2019).

A csecsemő-és kisgyermeknevelők többsége (61\%-a) 11-15 gyermekkel foglalkozik a csoportjában. A válaszok szerint kevés az alacsonyabb létszámú gyermekcsoport, holott ez a nyelvi fejlesztés minőségét és mennyiségét is erősen meghatározza. A kisebb létszámú csoportban a nevelőnek több ideje és energiája jut egy-egy gyermekre. Több lehetősége nyílik az egyéni nyelvi fejlesztésre és a speciális igényü kisgyermekek megsegítésére. A megfelelő csoportlétszám egyrészt feltétele a gyermek optimális fejlődésének, másrészt a nevelő számára is kedvezőbb munkakörülményeket és hatékonyabb munkavégzést jelent.

\begin{tabular}{|l|c|c|c|c|c|c|c|c|c|c|c|}
\hline Végzettség & $\%$ & $\begin{array}{c}\text { Munka- } \\
\text { évek száma }\end{array}$ & $\%$ & $\begin{array}{c}\text { Munkahely } \\
\text { (megye) }\end{array}$ & $\%$ & $\begin{array}{c}\text { Tele- } \\
\text { pülés }\end{array}$ & $\%$ & $\begin{array}{c}\text { A bölcsőde } \\
\text { típusa }\end{array}$ & $\%$ & $\begin{array}{c}\text { Csoport- } \\
\text { létszám }\end{array}$ & $\%$ \\
\hline MA & 2 & $0-5$ & 45 & Baranya & 33 & falu & 5 & $\begin{array}{c}\text { „klasszikus" } \\
\text { bölcsőde }\end{array}$ & 97 & $0-5$ & 16 \\
\hline BA & 34 & $6-10$ & 13 & Fejér & 33 & $\begin{array}{c}\text { kis- } \\
\text { város }\end{array}$ & 66 & mini & 0 & $6-10$ & 23 \\
\hline $\begin{array}{l}\text { OKJ/ } \\
\text { FOKSZ/ } \\
\text { FSZ }\end{array}$ & 47 & $11-30$ & 13 & Tolna & 34 & $\begin{array}{c}\text { nagy } \\
\text { város }\end{array}$ & 29 & magán & 3 & $11-15$ & 61 \\
\hline középfokú & 17 & $31-$ & 29 & - & - & - & - & munkahelyi & 0 & - & - \\
\hline
\end{tabular}

3. táblázat: A demográfiai adatok összesítése

\subsection{A nyelvi fejlesztés technikái}

Megkérdeztük a kérdőíveket kitöltő pedagógusoktól, hogy a kommunikációs módszerek (kérés, utasítás, magyarázat, kérdezés) közül, melyeket részesítik előnyben. A módszerek használatának gyakoriságát a válaszadóknak 1-től 5-ig terjedő skálán kellett jelölniük. A kapott eredményeket az 1. ábra szemlélteti. A dialógust leginkább fenntartó funkciója a kérdezésnek van, ezt a kisgyermeknevelők egy harmada nem alkalmazza, másik har- mada szerint is csak mérsékelten fontos és csupán egy harmaduk állítja, hogy gyakran alkalmazza a nap folyamán. A párbeszédnek lényeges eleme a kérdezés: megteremtheti a kontaktust, megindíthatja a beszélgetést, és lehetőséget biztosít a kapcsolat kibővítésére is. Fontos kiemelni, hogy kérdezés nélkül a kommunikáció elindítása és fenntartása akadályba ütközik, így az interakció sikertelenné válhat.

A válaszadók a kérés típusú kommunikációt tartották a legfontosabbnak. A kérésnek 
Kisgyermeknevelők nyelvi stratégiái a gyermeki kommunikáció támogatásában

valóban fontos szerepe van a kommunikáció zavartalan és gördülékeny lebonyolításában és az udvarias viselkedési szokások kialakításában, ugyanakkor, ha a nevelő a gyermektől csak a kérés végrehajtását igényli, akkor nem teremt beszédhelyzetet.

A kisgyermeknevelők körében az utasítás volt a legkevésbé preferált módszer. Megjegyezzük, hogy a kérés és az utasítás funkciói a kommunikáció lefolyását és kimenetét tekintve megegyeznek. Mindkettő befolyásoló módszer és előre közölt megoldást vár el. Az utasítás ugyanakkor direktebb és erőteljesebb felszólítást közvetít.

A válaszadók a második leggyakrabban használt módszerként a magyarázatot jelölték. A magyarázat monologikus módszer, mely főként az értést és megértést segíti elő és kevéssé teremt lehetőséget az interakcióra. Félő, hogy a magyarázat túlsúlyba kerülésével egyirányúvá válik a kommunikáció, és nem bontakozik ki olyan beszédszituáció, melybe a gyermek aktívan be tud kapcsolódni.

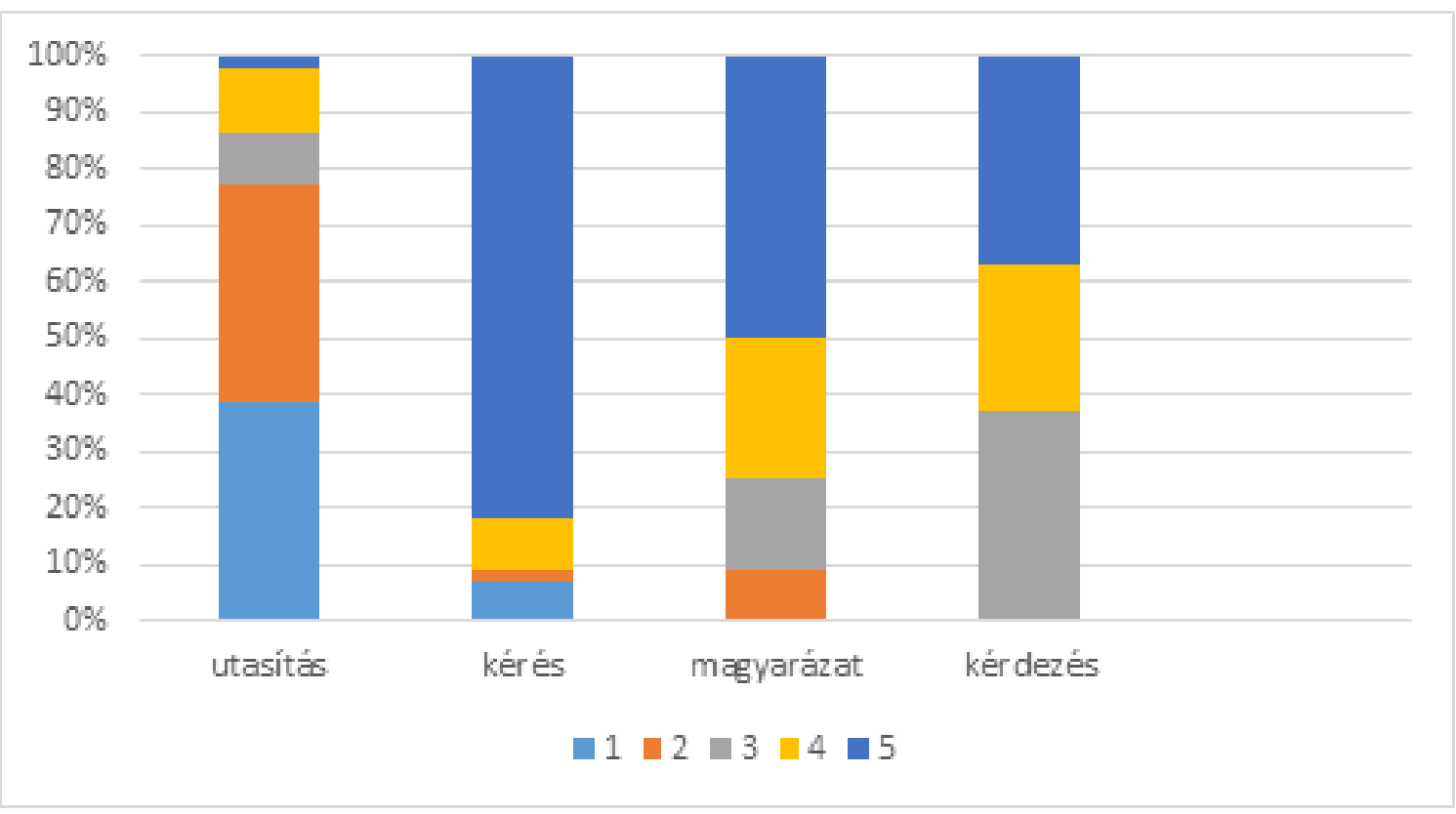

1. ábra: A bölcsődei tevékenységek során preferált kommunikációs formák

A kisgyermeknevelő fontos feladata a gyermek beszédelsajátításának segítése és támogatása. Ennek számos módszere ismert. Mi ezek közül a következő négy alkalmazására kérdeztünk rá:

1. Prezentáció: célforma bemutatása elsajátítás céljából (pl. Látod az autót? A piros autót? A pirosat!)

2. Párhuzamos beszéd: a gyermek szándékainak, jelzéseinek beszédbe foglalása (pl. A babát szeretnéd? Azt?)

3. Nyelvészeti markerek tudatos és hangsúlyos használata (pl. Látod a hó fehér? Megfogjuk a havat?)

4. Több nyelvi struktúra felkínálása (pl. Látod a babát? Látsz itt egy babát?)

A válaszadók a fenti lehetőségek közül választhattak, de ki is egészíthették új módszerekkel. A válaszok megoszlását a 2. ábra szemlélteti. A leggyakrabban alkalmazott módszerek a következők voltak: prezentáció, párhuzamos beszéd, nyelvi markerek hangsúlyos használata. Az alternatíva felkínálását kevesen jelölték, feltehetően ez a módszer kevéssé ismert és népszerü a kisgyermeknevelők körében. Sajnálatos, hiszen az alternatívák felkínálása elősegíti az egyes nyelvi struktúrák megértését, és megalapozza a választékos beszédet. Az alternatív struktúrák egyrészt figyelembe tudják venni az egyéni fejlődési sajátosságokat, másrészt sokféle módon tudják ugyanazt a tartalmat közvetíteni. Mindez a precízebb nyelvi értésnek és a jobb tárolásnak is előfeltétele. 


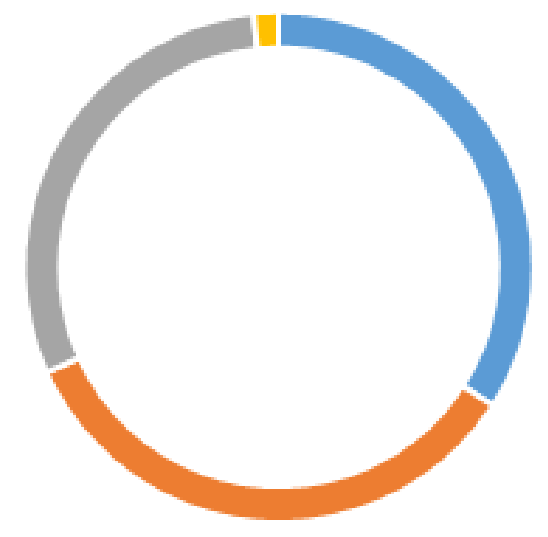

- prezent áció | párhuzamos beszéd || nyelvi markerek | alte nativ struktúrák felkínálása

2. ábra: Nyelvi eszközök alkalmazása a beszédfejlesztésben

Megvizsgáltuk, hogy a kisgyermeknevelök milyen formában reagálnak egy-egy gyermeki megszólalásra. A kérdőívben erre vonatkozóan az alábbi válaszlehetőségeket adtuk meg:

1. A gyermek beszédének kiegészítése, bővítése - igékkel, melléknevekkel, helyhatározóval stb. (pl. Vava el. - Igen, elszaladt a kutyus. Be a házába.)

2. A gyermek beszédének, mondatainak átformálása, más struktúra felkínálása. (pl. Vegyük ki a játékot? Kivesszük a játékot. Vegyük ki a játékot!)

3. A gyermek beszédének javítása. (pl. Peti tütű. - Peti autója, A te autód; Gabika ett. - Megetted? Ügyes vagy)

4. A gyermek beszédének utánzása és javítása. (pl. Peti tütű - Nem tütű, hanem autója; Gabika ett. - Nem, nem ett, hanem megette)

5. A gyermek beszédének folytatása. (pl. Gabika ett. - Megetted a fözeléket?)

A kisgyermeknevelők válaszait a 3. ábra öszszegzi. A nevelők körében a gyermek által elmondottak kiegészítése volt a legnépszerübb és legdominánsabb módszer, ezt követte a gyermek által mondottak folytatása, majd az átformálás, az új struktúra felkínálása. Meglátásunk szerint az átformálás (újrafogalmazás) módszerét célszerü lenne gyakrabban alkalmazni, hiszen ez a módszer egyrészt segítheti a megértést, másrészt változatosabbá teheti, bővítheti és színesítheti a gyermek nyelvhasználatát.

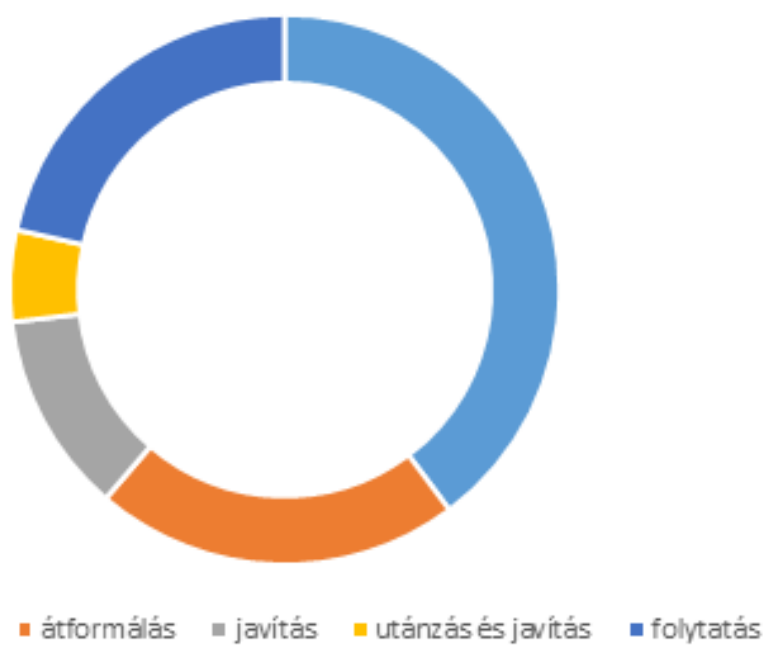

3. ábra: A gyermeki beszédprodukcióra adott reakciók 
Kisgyermeknevelők nyelvi stratégiái a gyermeki kommunikáció támogatásában

Az anyanyelv-elsajátítás fontos lépése, hogy a gyermekek megtanulják megfelelően használni nyelvi ismereteiket a hétköznapi szituációkban. Ez a pragmatikai kompetencia fejlődésével függ össze. A kisgyermeknevelőket arra kértük, hogy válasszák ki, milyen eszközöket ismernek és használnak csoportjukban a beszédmotiválására, a gyermekek nyelvi-kommunikációs igényeinek felkeltésére. A következő lehetőségek közül választhattak:

1. Humoros közlések használata. A gyermek számára is egyértelmüen hamis információk, állítások közlése, abból a célból, hogy azokat felismerje (pl. Az alma lila. Peti tud repülni.)

2. Dialógusok kialakítása és fenntartása játékeszközök segítségével (pl. képeskönyv, báb, mesepárna)

3. Közös gondolkodás a gyermekkel (együttes megfigyelés, problémamegoldás, tevékenység)

4. A dialógus kibővítése (további gyermekek bevonása a beszélgetésbe), a beszélgetés irányításának átengedése.

A válaszok megoszlását a 4. ábra szemlélteti. Megállapítható, hogy gyermekkel való közös gondolkodást, valamint az játékeszközökkel motivált dialógusok módszerét a nevelők jól ismerik, és gyakran alkalmazzák. Sajnos kevesen élnek a közösség adta kommunikációs lehetőségekkel. Nem vonnak be újabb gyermekeket egy-egy beszélgetésbe, hogy aztán hátra húzódva, segítő szerepben ösztönözzék őket az önálló párbeszédre és társalgásra. A hamis információk beépítését alig jelölték. Úgy tűnik, hogy ez a stratégia aggodalmat kelt a nevelők körében, holott a gyermekek nagyon élvezik. Jókat nevetnek az általuk felismert „butaságok” hallatán, és egymással versenyezve igyekeznek kijavítani a téves információkat. A humor hatását ebben az esetben az ismereti források (tapasztalat, logika) ellentmondása váltja ki a gyermekben. Hátterében, az esztétikai élményhez és a játék öröméhez hasonlóan, az ún. kollatív tulajdonságok állnak, például szokatlanság, kétértelműség, változás, inkongruitás, összeférhetetlenség (Séra, 1983). Ezek a jellemzők erősen vonzzák a figyelmet, érdekesnek és szokatlannak találja őket a gyermek. Érdemes még kiemelni a humoros közlések élményjellegét, a társas kapcsolatokra gyakorolt pozitív hatását. Természetesen a közlések megértésnek fontos előfeltétele a megfelelő szintű kognitív és nyelvi érettség.

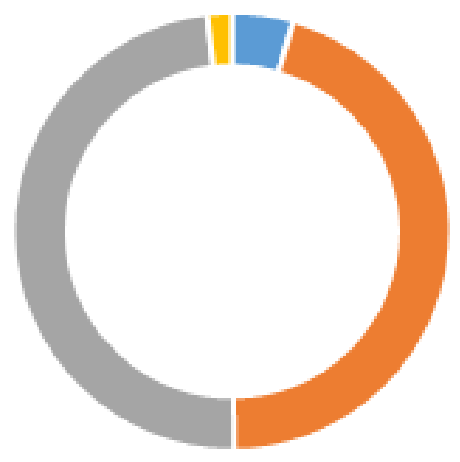

- nyilvánvalóan hamis információ | dialóguskialakitása

- közösgondolkodás

" más gyerek bevonása

4. ábra: A gyermeki beszéd motivációjának eszközei

Megvizsgáltuk azt is, hogy a kisgyermeknevelők hogyan viszonyulnak a dajkanyelvhez, használják-e a bölcsődei beszédhelyzetekben. A dajkanyelvet a kisgyermeknevelők 86 \%-a alkalmazza munkája során, és csupán 14 \%-uk tartja károsnak. Ez az arány örven- detes, hiszen a dajkanyelv a beszédadaptáció egyik fontos eszköze. Fő mozgatórugója a szociális közelség, azon belül is elsősorban a pozitív érzelmek. Segítségével a kisgyermeknevelők a saját nyelvi kompetenciáikat a gyermek biológiai, kognitív, szociális és 
ezzel együtt nyelvelsajátítási érettségi szintjéhez tudják igazítani (Kátainé, 2008). A dajkanyelvre jellemző jegyek (pl. dajkanyelvi szavak, reduplikáció, kicsinyítő vagy becéző képzés, széles gesztikuláció, változatos mimika stb.) használatával kinyilvánítják érzelmeiket, és ezzel a kötődést is erősítik. A dajkanyelv hangzásbeli tulajdonságai (pl. gyakoribb szünet, túlzott időtartambeli különbségek, nagyobb hangterjedelem, zeneiséget adó elemek stb.) közvetlen kapcsolatba hozhatók a nyelvi fejlődés elősegítésével. Támogatják az éppen elhangzó szöveg megértését, ugyanakkor az alkalmazkodás létrejöttével a szociális kapcsolódást, az együttműködést is megkönnyítik (Kohári, 2018).

\section{Implikációk}

Írásunkban a kisgyermeknevelők gyermeki kommunikációt támogató stratégiáit mutattuk be egy kérdőíves kutatás részeredményeinek tükrében. Megállapítható, hogy a gyermekekkel folytatott munka az ismereteken túl készségeket is igényel. Ezek biztosítják a hatékony kommunikációt a partnerek között, és segítik a nyelvi erőforrások és kompetenciák kibontakoztatását A kisgyermeknevelők professzionális kommunikációja, kompetens nyelvfejlesztő tevékenysége a következő tényezők összjátékából adódik: a) explicit, tudományos-elméleti ismeretek, b) implicit tapasztalati tudás, c) készségszintű (pl. módszertani, didaktikai, kommunikációs stb.) tudás. A tudás tehát magában foglalja mind az elméleti ismeretek rendszerét, mind pedig azok gyakorlati felhasználásának módozatait.

A különböző tudományterületekről származó tapasztalatok a korai interperszonális kapcsolat súlypontjait a kölcsönösség felé tolják el. A nevelő és a gyermek kapcsolatát olyan diadikus párként tekintik, amelyben kétoldalú - egymást alakító, fejlesztő és kiegészítő - hatás érvényesül (Dornes, 2002). Biztonságosnak és gondoskodónak azt a verbális környezetet tekintik, amelyben a nevelő verbálisan körülöleli a gyermeket. Tehát szenzitíven és rugalmasan alkalmazkodik nyelv- elsajátítási, kognitív és szocioemocionális szintjéhez, és támogató attitűdjével ösztönzi a nyelvi kompetenciák kiépülését és finomodását. Nyilvánvaló, hogy a pedagógiai kommunikáció színvonala megahatározó a gyermek fejlődése szempontjából. Az is nyilvánvaló, hogy a nevelő az adott helyzetben nemcsak kommunikációjával, de teljes személyiségével lép kapcsolatba a gyermekkel.

A pedagógusok kommunikációs kompetenciáit a csoportmódszerekre épülő képzések fejlesztik a leghatékonyabban. A csoportmódszerek (pl. workshopok, múhelymunkák, tréningek, érzékenyítő csoportok, encounter csoportok stb.) kiváló módszertani támogató erőként működnek: összekapcsolják az elméleti tudást és a gyakorlati tapasztalatokat. A csoportmódszerekben a hangsúly a készség- és/ vagy tudásfejlesztésre, az attitüdváltozásra helyeződik. Közös jellemzőjük, hogy védett környezetben zajlanak, a résztvevők aktivitására alapoznak, strukturált gyakorlatokra épülnek, és saját élményü, tapasztalati tanulást tesznek lehetővé (Buda, 2002). A saját élményü helyzetekben a kommunikációs technikákat és megoldásmódokat ki lehet próbálni, illetve analizálni és reflektálni lehet. A reflektálás különösen fontos, hiszen a visszajelentéseknek nagy az érlelő és korrektív hatása. A csoportmódszerek újszerü interperszonális találkozási élményt jelentenek és ösztönzik az egymástól való tanulást. Közvetlen kapcsolatot hoznak létre a mindennapi szituációkkal, így a tanultak könnyebben adaptálhatók a valós élethelyzetekre (Lakner, 2016). Megerősítik az önbizalmat, a kockázatvállalási készséget, és javítják az együttműködést. Felszínre hozhatnak általános emberi értékeket, etikai megfontolásokat, attitüdöket is, amelyeket aztán a gyakorlati munkában (szervezeti szinten is) alkalmazni lehet.

\section{Felhasznált irodalom}

Balogh Lászlóné, Barbainé Bérci Klára, Kovácsné Bárány Ildikó, Nyitrai Ágnes, Rózsa Judit Tolnayné Falusi Mária és Vokony Éva (2012): A bölcsődei nevelés-gondozás szakmai szabályai. Módszertani levél. Szociálpolitikai és Munkaügyi Intézet, Budapest. 
Kisgyermeknevelők nyelvi stratégiái a gyermeki kommunikáció támogatásában

Barton, M.. E. \& Tomasello, M. (1994): The rest of the familiy: the role of siblings and fathers in early childhood development. In: Gallaway, Clare, Richards \& Brian J. (Eds.): Input and Interaction in Language Acquisition. Cambridge University Press, Cambridge. 109-134. https://doi.org/10.1017/CBO9780511620690.007

Bates, E., Dale, P. S., Thal, D. (1995): Individual differences and their implications for theories of language development. In: Fletcher, P. \& MacWhinney, B. (Eds.) Handbook of Child Language. Basil Blackwell, Oxford, 96-151.

Bimbó Zoltánné (2015): A korai évek nevelését szolgáló tevékenységek. In: Nyitrai Ágnes (szerk.) Szemelvények a kisgyermeknevelés köréböl 2. Kaposvári Egyetem Pedagógiai Kar, Kaposvár

Bronfenbrenner, U. (1979): The Ecology of Human Development: Experiments by Nature and Design. Cambridge. Harvard University Press, Massachusetts.

Buda Béla (2002): A személyiségfejlődés és a személyiségfejlesztést szolgáló csoportmódszerek (Nemzetközi szakirodalmi helyzetkép). In: Buda Béla A mentálhigiéné szemléleti és gyakorlati kérdései: Újabb tanulmányok. Animula, Budapest, 53-76.

Buda Béla (2012): Empátia. A beleélés lélektana. Károli Gáspár Református egyetem L'Harmattan, Budapest.

Butzkamm, W. \& Butzkamm, J. (2008): Wie Kinder sprechen lernen. Francke Verlag Tübingen.

Dannenbauer, F. M. (1999): Grammatik. In: Baumgartner, S. \& Füssenich, I. Sprachtherapie mit Kindern. Reinhardt UTB, München. 105-161.

Dornes, Martin (200): A kompetens csecsemö: Az ember preverbális fejlődése. Pont, Budapest.

Farrar, M. J. (1992): Negative Evidence and Grammatical Morpheme Acquisition. Developmental Psychology, 28. 1. sz., 90-98. https://doi.org/10.1037/0012-1649.28.1.90

Fehérné Kovács Zsuzsanna, Kas Bence és Pintye Mária (2018): Szempontok a nyelvés beszédfejlödési zavarok szüréséhez és állapotmegismeréséhez. Családbarát Ország Nonprofit Kft., Budapest.

Fernald, A. (1985): Four-month-old infants prefer to listen to motherese. Infant Behavior and Development, 8. 2. sz., 181-195. https://doi.org/10.1016/S0163-6383(85)80005-9

Gecső Tamás szerk. (2006): Nyelvi kompetencia kommunikativ kompetencia. Tinta, Budapest.
Gósy Mária (2005): Pszicholingvisztika. Osiris, Budapest.

Gósy Mária (2017): Anyanyelv-elsajátítás: kutatási irányok, módszerek, lehetőségek. In: Bóna Judit (szerk.) Új utak a gyermeknyelvi kutatásokban. ELTE Eötvös, Budapest.

Grimm, H. (1999): Störungen der Sprachentwicklung. Hogrefe, Göttingen.

Kátainé Koós Ildikó (2008): Önzetlen dajkanyelv - ösztönös nyelvelsajátítás? A csecsemö-anya kommunikációs interakció néhány dajkanyelvi/Anyai sajátossága a magyar kultúrában. Doktori értekezés PTE BTK Nyelvtudományi Doktori Iskola Alkalmazott Nyelvészeti Doktori Program.

Klann-Delius, G. (1999): Spracherwerb. Metzler, Stuttgart. https://doi.org/10.1007/978-3-476-04036-7

Klein Ágnes (2013): Utak a kétnyelvüséghez. Tinta, Budapest.

Kohári Anna (2018): A dajkanyelv hangzásvilága. Édes anyanyelvünk. 40. 5. sz., 16.

Koós Ildikó (2017): A dajkanyelvnek is nevezett terminus technikus magyar nyelvü speciális jelentéstartalma In: Hajba Renáta és Tóth Péter (szerk.) „A véges végtelen”: Tanulmányok Vörös Ferenc 60. születésnapjára. Savaria University Press, Szombathely.

Központi Statisztikai Hivatal (2019): A gyermekek napközbeni ellátása, 2018. Statisztikai tükör. KSH.

URL: http://www.ksh.hu/docs/hun/ $\mathrm{xftp} /$ stattukor/kisgyermnapkozbeni/ kisgyermnapkozbeni18.pdf [2019. 03. 23.]

Krashen, S. (1985): The input hypothesis. Longman, London

Lakner Szilvia (2016): A felnöttképzési módszerek jelentősége és kihívásai az emberi erőforrás fejlesztési gyakorlatban. Lartco Consulting, Pécs.

Lengyel Zsolt (1981): A gyermeknyelv. Gondolat, Budapest.

Meisel, J. M. (2003): Zur Entwicklung der kindlichen Mehrsprachigkeit. Expertise als Beitrag zur 6. Empfehlung der Bildungskomission der Heinrich-Böll-Stiftung: Bildung und Migration. Heinrich-Böll-Stiftung, Berlin.

Murray, A. D., Fees, B.. S., Crowe, L. K., Murphy, M. E. \& Henriksen, A. L. (2006): The Language Environment of Toddlers in. Center-based Care versus Home Settings. Early Childhood Education Journal, 34. 3. sz., 233-339 https://doi.org/10.1007/s10643-006-0138-3 
Pléh Csaba (2006): A gyermeknyelv. In: Kiefer Ferenc (szerk.) A magyar nyelv. Akadémiai Kiadó, Budapest. 753-781.

Pléh Csaba, Palotás Gábor és Lőrik József (2002): PPL Nyelvfejlődési szürővizsgálat. Akadémiai Kiadó, Budapest.

Réger Zita (1986): A gyermeknyelvi utánzás kutatása a pszicholingvisztikában. Egy új szempont. Pszichológia, 6. 1. sz., 93-134.

Réger Zita (2002): Utak a nyelvhez. MTA Nyelvtudományi Intézet - Soros Alapítvány, Budapest.

Ritterfeld, U. (2000): Welchen und wieviel Input braucht ein Kind? In: Grimm, H. (Hrsg.) Enzyklopädie der Psychologie. CIII, Bd. 3, Sprachentwicklung. Hogrefe, Göttingen. 403-432.

Saxton, M. (2000): Negative evidence and negative feedback: immediate effects on the grammaticality of child speech. First Language 20., 221-252. https://doi.org/10.1177/014272370002006001

Séra László (1983): A nevetés és a humor pszichológiája. Akadémiai Kiadó, Budapest.

Szőke-Milinte Enikő (2013): A pedagógiai kommunikáció értelmezései. In: Karlovitz János T. és Torgyik Judit (szerk.) Vzdelávanie, výskum a metodológia: Oktatás, kutatás és módszertan. International Research Institute, Komárno, 241-249.
Tancz Tünde (2011): A kommunikáció és a nyelv fejlődése a kora gyerekkorban. Pécsi Tudományegyetem Bölcsészettudományi Kar.

URL: http://janus.ttk.pte.hu/tamop/ tananyagok/kommunikacio_es_fejlodes/ index.html [2019. 09. 23.]

Weber-Fox, Ch. \& Neville, H. J. (1996): Maturational constraints on functional specializations for language processing: ERP and behavioral evidence in bilingual speakers. Journal of Cognitive Neuroscience. 8. 3. sz., 231-256. https://doi.org/10.1162/jocn.1996.8.3.231

Zrinszky László (2002): Gyakorlati pedagógiai kommunikáció. ADU-Fitt Image, Budapest.

\section{Hivatkozott jogszabályok}

1997. évi XXXI. törvény a gyermekek védelméről és a gyámügyi igazgatásról.

15/1998. (IV. 30.) NM rendelet a személyes gondoskodást nyújtó gyermekjóléti, gyermekvédelmi intézmények valamint személyek szakmai feladatiról és működésük feltételeiről 10. sz. melléklete

381/2017. (XII. 11.) Korm. rendelet a szociális, gyermekjóléti és gyermekvédelmi szolgáltatásokkal összefüggő egyes kormányrendeletek módosításáról.

\section{Early childhood educators' language strategies of the assistance of children's communication}

Questions related to the acquisition of the mother tongue have long been of concern to researchers from different disciplines (eg. Philosophy, psychology, pedagogy, linguistics etc.). In recent years, numerous studies have focused on children's linguistic development, stages and characteristics of development, early recognition and therapy of different language development. In addition, a comprehensive analysis of linguistic development and assessment of development opportunities require the emphasis in linguistic input. According to the „input hypothesis" (Krashen, 1985), language acquisition can only be achieved through the quantity and quality of linguistic effects, the child should be provided with appropriate language patterns and support in early childhood. The Human Ecological Approach (Bronfenbrenner, 1979) emphasise the importance of the environment in the development of the child and combines individual living conditions and socio-cultural influences. Age is important for linguistic input. The brain is most receptive to language acquisition during the sensitive period, after which the development is slower and result is not perfect. In early childhood, linguistic input undeniably comes from mothers and the immediate family environment and institutionalized education broadens the language resources and influences. The present study demonstrates the strategies that affect language acquisition in early childhood interactions and focuses on the ability of these strategies to provide the child with the language development needed at given age.

Keywords: language acquisition, institutional language development in early childhood, baby talk, pedagogical communication, child-adult interaction 